\title{
EFFECT OF LIGHT-EMITTING DIODES (LEDS) ON SOME PHYSICAL AND BIOACTIVE COMPOUNDS OF 'ICEBERG' LETTUCE (LACTUCA SATIVA L.)
}

\author{
Asmaa Sayed AHMED ${ }^{1}$, Arshad Abdulkhalq YASEEN ${ }^{1,2 *}$, Triska Dlshad BAKR ${ }^{1,3}$ \\ ${ }^{1}$ Department of Horticulture, College of Agricultural Engineering Sciences, Salahaddin University- \\ Erbil, 44002 Kurdistan Region, Iraq \\ ${ }^{2}$ Institute of Horticultural Sciences, Faculty of the Agricultural and Food Sciences and \\ Environmental Management, University of Debrecen, H-4032 Debrecen, Böszörményi Street 138 \\ ${ }^{3}$ Khabat Technical Institute, Department of Horticulture' Erbil Polytechnic University, Erbil, \\ Kurdistan Region, Iraq
}

*Correspondence:

Arshad Abdulkhalq YASEEN

arshadabdulkhalq@gmail.com

Received: 15 May 2021; Accepted: 26 May 2021; Published: 30 June 2021

\begin{abstract}
The use of light-emitting diodes (LEDs) is a recent concerned application in the indoor crop system of the modern plant production. In our research, we evaluated the influence of four monochromic LED lights including 100\% White (W), Yellow (Y), Red (R) and Blue (B) in comparison to solar lightening condition (GR) as a control. In this regard, some morphological characteristics and biochemical content of the common outdoor 'Iceberg' lettuce (Lactuca sativa L.) was measured. The results show that leaf length, leaf area and total head weight were significantly greater in the plants grown under B LED, while all the other physical parameters were significantly higher in the plants grown under GR environmental conditions. On the other hand, chlorophyll (Chl), carotenoids (Car), and nitrate content were also influenced by different light treatments. Plants grown under LED light treatment resulted in significantly higher chlorophyll content compared to the control. However, significantly greater carotenoid content was in the plants grown under GR condition. The highest total chlorophyll content was recorded under B and R LED, whereas the lowest was in the GR condition. The lowest nitrate content in the blade and petiole was recorded in the plants grown under Y LED, while the highest nitrate content was recorded in the GR. Based on our result, it is possible to grow and improve some quality parameters of common outdoor 'iceberg' lettuce under LED where the solar light is limited or unavailable. Thus, plants performed better under GR light conditions than monochromic LEDs; however, some LED lights could improve some quality parameters and biochemical contents in the 'iceberg' lettuce variety.
\end{abstract}

Keywords: LED light, morphological parameters, bioactive contents, common outdoor 'iceberg' lettuce (Lactuca sativa L.), nitrate content.

\section{Introduction}

The Light spectrum determines most of the morphological formation and biochemical content in leafy vegetables through photosynthetic apparatus, which gives the vigor power to the plant (Walters, 2005; Matsuda et al., 2007). Improvement of vegetable quality and year-round cultivation with a minimum cost, safe to the environment and lower energy consumption is the current interest among crop growers (Pinho et al., 2012). Scientists have 
shown the photoreceptors like phytochrome, cryptochrome and phototropin, which have the main role of photosynthetic efficiency in plants, are affected by light quality and this leads to gene expressions through initiating the signaling cascade (Lillo and Appenroth, 2001; Giliberto et al., 2005).

In recent years, the new inventions in lightening as the use of LEDs in horticulture crop production that has a tremendous revolution in high-tech greenhouses and this has inspired continuous development in plant growth and development (Massa et al., 2008). Plants require specific light (short and long) wavelengths depending on the growing cycle, blue light is needed for the stomatal opening and chloroplast development (Cosgrove and Green, 1981; Akoyunoglou and Anni, 1984; Schwartz and Zeiger, 1984; Takemiya et al., 2007), $\mathrm{CO}_{2}$ exchange, stem elongation and phototropism (Blaauw and Blaauw-Jansen, 1970; Cosgrove and Green, 1981). Meanwhile $\mathrm{R}$ light is for seed germination and photosynthesis apparatus (McAllister, 1937; Balegh and Biddulph, 1970; Sæbø et al., 1995), flowering stimulation (Deitzer et al 1979), and internode elongation (Morgan and Smith, 1979). Many studies have shown a positive influence of the combination of B and R LED on lettuce growth and development (Yanagi et al., 1996; Lee et al., 2007; Chen et al., 2014; Amoozgar et al., 2017; Naznin et al., 2019), while very limited research on a monochromic LED light in comparison to the normal light spectrum has been conducted. The first suggested research on the combination of $\mathrm{R}$ and B lights on lettuce growth was by Bula et al. (1991), thereby they found lettuce seedlings faced etiolation under the influence of the monochromic R LED. Subsequently, Hoenecke et al. (1992) mentioned that it is necessary to mix some blue light with $\mathrm{R}$ to get adequate plant growth in lettuce seedling production. This is because plants naturally grow under artificial light mixtures or normal sunlight (Kim et al., 2004; Matsuda et al., 2007). Although, it is confirmed that $\mathrm{R}$ and $\mathrm{B}$ lights are the most important lights in the improvement of photosynthesis, produce greater biomass, lower nitrate content in lettuce plant (Lin et al., 2013). Other monochromatic lights which are in between $400 \mathrm{~nm}$ and 700 nm PAR spectral region such as violet, white, green, yellow, orange and even invisible light spectrums under 400 as UV and above $700 \mathrm{~nm}$ as infrared has to be tested on the plants too, since they might have a similar or even greater result on the plant performance. UV light may have the same influence as blue light (Senger, 1984), since phytochrome is influenced by a small amount of far-red radiation (Yorio et al., 2001). On the other hand, W LED incorporates $\mathrm{R}$ and $\mathrm{B}$ lights, so that plants can survive under W light (Chen et al., 2016), where W LED is also typically used for general illumination and cultivation of plants (Lin et al., 2013).

'Iceberg' lettuce variety is a common outdoor cultivated lettuce in the USA and the Middle East, besides there is no or very limited research on the plant influences by LED (Amoozgar et al., 2017). The nature of the plant reactions for specific light has to be addressed in the use of modern technology for plant growth and development. Thus, this research aimed to investigate the response of a common outdoor Crisphead lettuce variety 'Iceberg' to different LED lightning in comparison to the GR (control) light condition.

\section{Materials and methods}

\subsection{Experimental set-up and growth conditions}

Seeds of 'iceberg' lettuce were sown in a tray with 80 cells containing peat-moss only. Twenty-five days after the seed sowing, the seedlings were transplanted under the custommade lighting equipment. The homogenized 
seedlings were transplanted in four plastic pots with $25 \mathrm{~cm}$ in height and $25 \mathrm{~cm}$ in diameter in the top and $15 \mathrm{~cm}$ at the base. Four growth cabinets with a size of $80 \mathrm{~cm}$ height $60 \mathrm{~cm}$ length were prepared in a complete dark laboratory room to the (four light treatments) or light-emitting diodes (LEDs). The boxes were covered with aluminum foil to avoid light absorption. The light treatments were installed in four separate cabinets. The LED lamps generate included 100\% White (W) (430 nm and $582 \mathrm{~nm})$, Yellow (Y) $(570 \mathrm{~nm})$, Red (R) $(660 \mathrm{~nm})$, Blue (B) (460 nm). Four pots were placed under each light treatment and one seedling was grown in each pot. All the pots were filled with the same substrate (peat-moss) under the same environmental condition except for the control (GR) treatment. Similar to the LED treatments, four pot seedlings were also grown with the same size and substrate, but under the optimal condition in a greenhouse (GR) as the control. The seedlings under LED light treatments were supplied the light treatment of $16 / 8$ (day/night), RH of $65 \% \pm 5$, and the temperature of $18-20{ }^{\circ} \mathrm{C}$ for 22 days, while plants under control condition rely on the sunlight 10/14 day/night light duration with the same temperature $18-20^{\circ} \mathrm{C}$.

\subsection{Measurements of plant growth and morphology}

To measure the morphological characters such as head weight, leaf number, leaf width, leaf length and leaf area, three plants were considered on the day of 22 from transplanting as the replication per light treatment. All the parameters were directly measured from fresh leaves on the harvesting day. The millimeter graph paper method was performed to measure the lettuce leaf area $\left(\mathrm{cm}^{2}\right)$ as described by Pandey and Singh (2011) based on the following equation:

$$
\text { Leaf area }\left(\mathrm{cm}^{2}\right)=x / y
$$

$\mathrm{x}$ : is the weight $(\mathrm{g})$ of the area covered by the leaf outline on a millimeter graph paper

$y$ : is the weight of one $\mathrm{cm}^{2}$ of the same graph paper

\subsection{Determination of nitrate}

A simple method and portable apparatus were performed a quick measure of nitrate level in fresh lettuce leaf blade $\left(\mathrm{mg} \mathrm{kg}^{-1}\right)$ and petiole $\left(\mathrm{mg} \mathrm{kg}^{-1}\right)$ using Green test eco with margin error of about $10 \%$ as it is done by Klemo and Biti (2018).

\subsection{Pigment measurement}

Fresh lettuce leaf (0.5) g was grounded in a mortar and pestle. The grounded leaf was submerged in $10 \mathrm{ml}$ of $80 \%$ acetone till the leaf color turned to white. The homogenized extracted juice was then centrifuged in 80-2 tabletop low speed centrifuge $4000 \mathrm{rpm}$ for 15 $\min$ at $4{ }^{\circ} \mathrm{C}$. The solution mixture was analyzed for chlorophyll a (Chl a), chlorophyll b ( Chl b), total chlorophyll (Chl a+ Chl b) and carotenoids (Car) content in UV/Visible spectrophotometer at A663 $\mathrm{nm}$ Chl a, A646 $\mathrm{nm}$ $\mathrm{Chl} \mathrm{b}$, and $\mathrm{A} 470_{\mathrm{nm}}$ Car. Then the achieved data was calculated based on the following equations by Sumanta et al. (2014) (Table 1):

$$
\begin{aligned}
& \text { Chl } \mathrm{a}=12.25 \mathrm{~A}_{663}-2.79 \mathrm{~A}_{646} \\
& \mathrm{Chl} \mathrm{b}=21.5 \mathrm{~A}_{646}-5.1 \mathrm{~A}_{663} \\
& \text { Total Chl }(\mathrm{a}+\mathrm{b})=7.15\left(\mathrm{~A}_{663}\right)+18.71\left(\mathrm{~A}_{646}\right) \\
& \mathrm{Car}=\left(1000 \mathrm{~A}_{470}-1.82 \mathrm{Chl} \mathrm{a}-85.02 \mathrm{Chl}\right.
\end{aligned}
$$
b)/198

\subsection{Statistical analysis}

The data were analyzed using one-way analysis of variance (ANOVA), combined with Duncan's multiple range tests at the confidence levels of $p<0.05$ using SPSS statistical analysis software version 25.0. The mean value and standard errors were expressed in Excel software. 
Table 1. Spectrophotometric determination of absorbance for Chlorophyll a, Chlorophyll b and Carotenoids using $80 \%$ acetone as a solvent

\begin{tabular}{|l|l|l|l|}
\hline Light treatment & Chl a $\left(\mathbf{A}_{\mathbf{6 6 3}} \mathbf{n m}\right)$ & Chl b $\left(\mathbf{A}_{\mathbf{6 4 6}} \mathbf{n m}\right)$ & Car $\left(\mathbf{A}_{\mathbf{4 7 0}} \mathbf{n m}\right)$ \\
\hline GR & 0.229 & 0.161 & 1.367 \\
\hline W LED & 0.532 & 0.298 & 1.184 \\
\hline Y LED & 0.878 & 0.599 & 1.144 \\
\hline R LED & 0.594 & 0.433 & 1.144 \\
\hline B LED & 1.209 & 0.535 & 1.150 \\
\hline
\end{tabular}

Note: $\mathrm{Ch}$ a $=$ Chlorophyll $\mathrm{a}, \mathrm{Ch} \mathrm{b}=$ Chlorophyll $\mathrm{b}, \mathrm{Car}=$ Carotenoids

\section{Results}

\subsection{Plant morphology and growth characteristics}

The morphological characteristics of lettuce were statistically influenced by the light spectra treatments. Based on the data from (Table 2), plants grown in the GR condition responded greater than under the artificial light (LEDs) condition. Leaf number, for example, was significantly higher in the plants grown under the GR (13.25) than under LEDs. Plants also reacted positively under different LED treatments themselves, for example, plants under 430, $582 \mathrm{~nm}$ (W LED) formed significantly more leaves (10.63), while the least leaf number was under the longest wavelength $660 \mathrm{~nm}$ R LED (7.62). The greatest positive influence of $460 \mathrm{~nm}$ Blue light was found on the leaf expansion (leaf length) and leaf area at $17.03(\mathrm{~cm})$ and $74.84\left(\mathrm{~cm}^{2}\right)$ respectively, while the lowest result was for the plants grown under W LED at $14.50(\mathrm{~cm})$ and $24.96\left(\mathrm{~cm}^{2}\right)$ respectively. Significant greater leaf width was for the plants under GR light condition followed by $\mathrm{W}, \mathrm{B}, \mathrm{Y}$ and $\mathrm{R}$ LED light treatments. Significantly greater head weight was recorded in the plants grown under GR and B LED at 8.19 and 8.18 (g), while the lowest head weight was in the plants grown under W, R and Y LED at 4.56, 5.17 and 5.63 (g) respectively. Significantly bigger fresh head weight was under GR growth condition rather than LED light treatments (Table 2).

Table 2. Influence of light quality on leaf number, leaf length, leaf width, leaf area, and head fresh weight of Iceberg lettuce 22 days after transplanting

\begin{tabular}{|c|c|c|c|c|c|c|}
\hline \multirow{2}{*}{$\begin{array}{c}\text { Light } \\
\text { treatment }\end{array}$} & $\begin{array}{c}\text { Peak } \\
\text { wavelength } \\
(\mathbf{n m})\end{array}$ & \multicolumn{5}{|c|}{ Parameters } \\
\cline { 3 - 7 } & $\begin{array}{c}\text { Leaf } \\
\text { number }\end{array}$ & $\begin{array}{c}\text { Leaf length } \\
(\mathbf{c m})\end{array}$ & $\begin{array}{c}\text { Leaf width } \\
(\mathbf{c m})\end{array}$ & $\begin{array}{c}\text { Leaf area } \\
\left(\mathbf{c m}^{2}\right)\end{array}$ & $\begin{array}{c}\text { Head weight } \\
(\mathbf{g})\end{array}$ \\
\hline GR & & 13.25 & 12.93 & 7.58 & 51.65 & 8.19 \\
& & $\pm 1.28^{\mathrm{a}}$ & $\pm 1.21^{\mathrm{c}}$ & $\pm 1.25^{\mathrm{a}}$ & $\pm 3.09^{\mathrm{b}}$ & $\pm 0.73^{\mathrm{a}}$ \\
\hline W LED & $(430,582)$ & 10.63 & 14.50 & 5.34 & 24.96 & 4.56 \\
& & $\pm 1.92^{\mathrm{b}}$ & $\pm 2.38^{\mathrm{bc}}$ & $\pm 0.88^{\mathrm{b}}$ & $\pm 3.05^{\mathrm{c}}$ & $\pm 0.42^{\mathrm{b}}$ \\
\hline Y LED & 580 & 8.63 & 14.53 & 4.38 & 44.84 & 5.63 \\
& & $\pm 1.30^{\mathrm{c}}$ & $\pm 1.95^{\mathrm{bc}}$ & $\pm 0.92^{\mathrm{bc}}$ & $\pm 5.673^{\mathrm{b}}$ & $\pm 0.34^{\mathrm{b}}$ \\
\hline R LED & 660 & 7.62 & 15.00 & 3.43 & 49.43 & 5.17 \\
& & $\pm 1.60^{\mathrm{c}}$ & $\pm 1.16^{\mathrm{b}}$ & $\pm 0.76^{\mathrm{c}}$ & $\pm 1.82^{\mathrm{b}}$ & $\pm 0.70^{\mathrm{b}}$ \\
\hline B LED & 460 & 8.50 & 17.03 & 4.61 & 74.84 & 8.18 \\
& & $\pm 1.85^{\mathrm{c}}$ & $\pm 2.26^{\mathrm{a}}$ & $\pm 0.99^{\mathrm{b}}$ & $\pm 7.72^{\mathrm{a}}$ & $\pm 1.16^{\mathrm{a}}$ \\
\hline
\end{tabular}

Note: Mean values \pm SD with same letter are not significantly different at $p \geq 0.05$ with Duncan multiple range test; Values in each column are mean $\pm \mathrm{SD}(\mathrm{n}=8)$. GR is the control (Greenhouse), W LED is WHITE light, Y LED is YELLOW light, R LED is RED light, B LED is BLUE light 


\subsection{Chlorophyll and carotenoid contents}

In general, pigment accumulation in the plant grown under light-emitting diodes (LEDs) resulted in significantly higher than under greenhouse conditions (Fig. 1 and 2). Figure 1 demonstrates that chlorophyll concentration had a distinct response to different LED light treatments, too. The Chl a content in the lettuce leaves is higher than $\mathrm{Chl}$ $\mathrm{b}$ in all the light treatments including the GR. Plants under $460 \mathrm{~nm}$ B LED produced significantly higher $\mathrm{Chl}$ a content, while the control treatment was the lowest Chl a. However, the main significant difference of the $\mathrm{Chl} \mathrm{b}$ was in the plants grown under $580 \mathrm{~nm} \mathrm{Y}$ LED and the lowest was under GR treatment. Total chlorophyll was significantly higher under $460 \mathrm{~nm}$ B LED followed by $570 \mathrm{~nm} \mathrm{Y}$ LED at 18.85 and $17.48 \quad\left(\mathrm{mg} . \mathrm{mL}^{-1}\right)$ respectively (Fig. 1). Figure 2 indicates that lettuce leaves grown under GR light condition recorded a significantly greater carotenoid content at $5.89\left(\mathrm{mg} . \mathrm{mL}^{-1}\right)$ compare to the LED lighting conditions.

Different LED colors have also impacted the carotenoid pigment content. 430, $582 \mathrm{~nm} \mathrm{~W}$ and $460 \mathrm{~nm}$ B LED recorded the highest carotenoid content 4.081 and $3.395\left(\mathrm{mg} \mathrm{mL}^{-1}\right)$ respectively, whereas $580 \mathrm{~nm}$ Y LED was the most influenced light treatment on the leaf carotene content by recording the lowest content followed by $660 \mathrm{~nm}$ R LED at 2.09 and $3.02\left(\mathrm{mg} . \mathrm{mL}^{-1}\right)$ respectively.

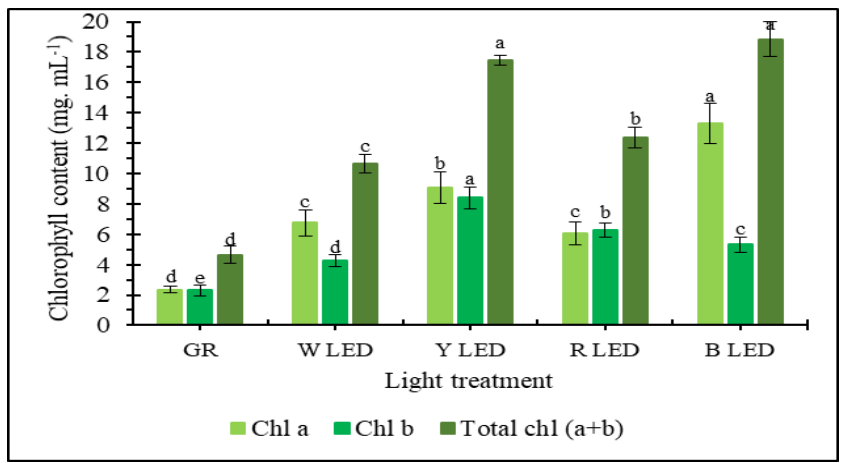

Fig. 1. Chlorophyll content under the influence of various light treatments. Error bars indicate standard deviation (SD); Similar letters are not significantly different at Duncan multiple range test $\mathrm{p} \geq 0.05$; GR is the control (Greenhouse), W LED is WHITE light, Y LED is YELLOW light, $\mathrm{R}$ LED is RED light, B LED is BLUE light

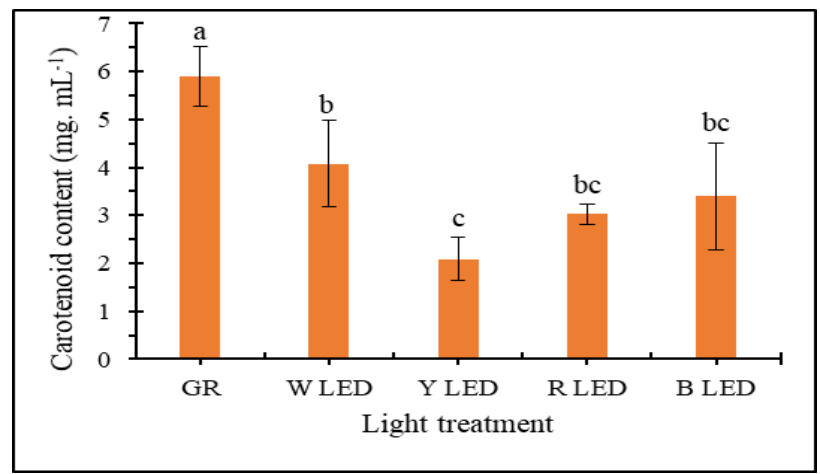

Fig. 2. Carotenoids content under the influence of various light treatments. Error bars indicate standard deviation; Similar letters are not significantly different at Duncan multiple range test $\mathrm{p} \geq .05$ GR is the control (Greenhouse), W LED is WHITE light, Y LED is YELLOW light, R LED is RED light, B LED is BLUE light 
The GR treatment was adverse to chlorophyll pigment accumulation, while it is more appropriate to carotenoids.

\subsection{Nitrate content in lettuce leaves}

(mg. $\mathrm{kg}^{-1}$ )

Nitrate concentration in lettuce leaf blade and petiole was different between the plant growth conditions (GR and LEDs). Statistically, the lowest nitrate accumulation in leaf blade was in the $580 \mathrm{~nm}$ Y LED at 112.43 $\left(\mathrm{mg} . \mathrm{kg}^{-1}\right)$, whereas, there were similar and non-significantly different among other treatments. Also, the lowest nitrate content in leaf petiole was recorded in $580 \mathrm{~nm}$ Y LED and GR (control) at 63.33 and 115.00 (mg. kg$\left.{ }^{1}\right)$ respectively, while the highest nitrate content was recorded in the plants grown under B LED followed by W and R LED at 496.67, 316.67 and 298.67 (mg. $\mathrm{kg}^{-1}$ ) respectively. In general, nitrate concentration was far much higher in the leaf petiole than in the blade (Fig. 3A and B).
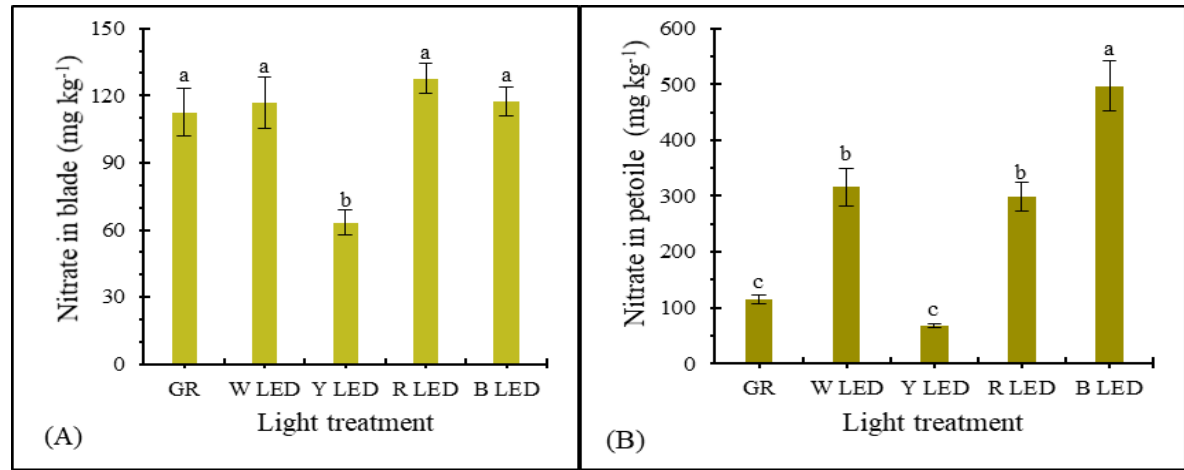

Fig. 3. Nitrate level in lettuce leaf blade (A) and petiole (B) under the influence of various light treatments. Error bars indicate standard deviation; Similar letters are not significantly different at Duncan multiple range test $p \geq 0.5$; GR is the control (Greenhouse), W LED is WHITE light, Y LED is YELLOW light, R LED is RED light, B LED is BLUE light

\section{Discussion}

The majority of morphological parameters (leaf number, leaf width, head fresh weight) were significantly greater in the 'Iceberg' lettuce grown under GR light condition. On the contrary, higher biochemical contents (pigments) were obtained in the lettuce leaves grown under light emitting diodes (LEDs). This results agree to the result observed by Fan et al., (2013) where they found the best pigment accumulation in Chinese cabbage grown under mixture R/B LED and Dysprosium lamp rather than monochromic LED lights. Among the LED light treatments, the greatest chlorophyll pigments were observed in the seedlings grown under $\mathrm{B}$ and $\mathrm{Y}$ LED, whereas carotenoid pigment under $\mathrm{W}$ and $\mathrm{B}$ LED. Researchers agree that blue light is more beneficial to the pigment accumulation in plants (Kurilčik et al., 2008; Poudel et al., 2008) since plants under long term blue light improve the ALAsynthesizing activity (Kamiya et al., 1981). Plants cultured under GR produced significantly more leaves than under monochromic LEDs. Only leaf length and leaf area were significantly higher under the $\mathrm{B}$ LED. A similar result was recorded by Hogewoning et al. (2010) where they found that Cucumis leaf was significantly increased under blue light irradiation compare to R LED. Solar light contains all the light spectrums so that plants having more than a single light can perform better in improving pigment content, 
biomass and morphological characteristics (Chen et al., 2014). Lettuce seedlings responded differently among the LEDs, too. Some LED lights influenced negatively on some physical quality parameters, whereas positive impacts were found for some chemical contents as nitrate level.

In general, the lowest morphological parameters (leaf and head biomass) were in the plants grown under R LED. Brown et al. (1995) demonstrated that pepper grown under R LED produced significantly lower biomass in comparison to those cultured under B LED and broad spectrum metal halide (MH) lamps.

Lower nitrate accumulation is considered as a better quality in leafy vegetables (Santamaria, 2006) since it influences human health while converted to nitrite. Among the LED light treatments, we observed that lettuce under Y LED accumulated significantly lower nitrate content in both leaf blade and petiole, whereas the highest nitrate was found in the plants grown under the B LED (496.67 mg.kg${ }^{1}$ ) in the leaf petiole, this might be because of changes in some regulatory mechanism in the plant (Chen et al., 2014) or the nitrate reductase genes of messenger RNA in the plant cells (Lillo, 1994). Matsuda et al. (2007) have also found that nitrogen level increased per unit leaf area in Spinach (Spinacia oleracea L.) with increasing blue-light PFD up to $100 \mu \mathrm{mol} \mathrm{m} \mathrm{m}^{-2}$ $\mathrm{s}^{-1}$.

In our research, leaf morphological abnormality was found in the 'iceberg' lettuce cultured under red light, while some chemical contents respond positively with red light such as total chlorophyll and carotenoids. Y LED, for example, resulted in the lowest nitrate content in the lettuce blade and petiole however, lower fresh biomass was performed in comparison to other lights including GR (control). The higher chlorophyll content in the plants grown under B LED light might be due to the stomatal opening which B LED is known for controlling stomal opening in plant leaves (Sharkey and Raschke, 1981; Zeiger, 1984). The greater chlorophyll content and leaf area were found in the cultures irradiated with B LED. Similar results were recorded by Sæbø et al. (1995) working on in vitro culture of Betula pendula Roth under red and blue light. Naznin et al., (2019) have discovered that pigments (Chl a, Chl b, and total Chl) in lettuce and basil increased with the increase of $B$ LED lightening percentage to R LED. Other research studies have proven the greater chlorophyll (Chl) a/b ratio in the plants grown under B light (Leong and Anderson, 1984; Lopez-Juez and Hughes, 1995).

In this research, we found significantly higher carotenoid content in the GR, while the lowest was recorded in the monochromic Y LED. Chen et al. (2014) have found significantly greater chlorophyll and carotenoids in the plants grown under fluorescent light compare to the other monochromic LED lights.

\section{Conclusions}

This research shows the potential irradiation source for indoor lettuce production. It also demonstrates that not only B and R LED are important for the modern lettuce production technics, but other LEDs like $\mathrm{Y}$ and $\mathrm{W}$ can positively influence some lettuce quality parameters and they might be more suitable in proper combination with other wavelengths of light. Strategically, light emitting diodes might be the most appropriate alternative to solar light. However, monochromic lights are unprofitable for the morphological parameters of outdoor lettuce. It is also important to determine other tests on the influence of LED on the common outdoor lettuce variety 'Iceberg'. 


\section{Conflict of interest}

The authors have declared that there is no conflict of interest.

\section{References}

1. Akoyunoglou G, Anni H (1984) Blue light effect on chloroplast development in higher plants. In Blue light effects in biological systems. Springer, Berlin, Heidelberg.

2. Amoozgar A, Mohammadi A, Sabzalian MR (2017) Impact of light-emitting diode irradiation on photosynthesis, phytochemical composition and mineral element content of lettuce cv. Grizzly. Photosynthetica 55:85-95. doi: 10.1007/s11099-016-0216-8

3. Balegh S, Biddulph O (1970) The Photosynthetic Action Spectrum of the Bean Plant. Plant Physiol 46:1-5.

4. Blaauw OH, Blaauw-Jansen G (1970) The phototropic responses of Avena coleoptiles. Acta Botanica Neerlandica 19:755-763.

5. Brown C s., Schuerger AC, Sager JC (1995) Growth and photomorphogenesis of pepper plants under red light-emitting diodes with supplemental blue or far-red lighting. Journal of the American Society for Horticultural Science 120:808-813. doi: 10.1016/j.envexpbot.2009.06.011

6. Bula RJ, Morrow RC, Tibbitts TW, et al (1991) Light-emitting Diodes as a Radiation Source for Plants. HortScience 26:203-205. doi: 10.1007/s004420050624

7. Chen X li, Guo W zhong, Xue X zhang, et al (2014) Growth and quality responses of "Green Oak Leaf" lettuce as affected by monochromic or mixed radiation provided by fluorescent lamp (FL) and light-emitting diode (LED). Scientia Horticulturae 172:168-175.

doi: 10.1016/j.scienta.2014.04.009
8. Chen X li, Xue X zhang, Guo W zhong, et al (2016) Growth and nutritional properties of lettuce affected by mixed irradiation of white and supplemental light provided by light-emitting diode. Scientia Horticulturae 200:111-118.

doi: 10.1016/j.scienta.2016.01.007

9. Cosgrove DJ, Green PB (1981) Rapid Suppression of Growth by Blue Light. Plant Physiology 67:584-590. doi: 10.1104/pp.68.6.1447

10. Deitzer GF, Hayes R, Jabben M (1979) Kinetics and Time Dependence of the Effect of Far Red Light on the Photoperiodic Induction of Flowering in Wintex Barley. Plant Physiology 64:10151021. doi: 10.1104/pp.64.6.1015

11. Fan X, Zang J, Xu Z, et al (2013) Effects of different light quality on growth , chlorophyll concentration and chlorophyll biosynthesis precursors of non-heading Chinese cabbage Effects of different light quality on growth, chlorophyll concentration and chlorophyll biosynthesis precursor. Acta physiologiae plantarum 35:2721-2726. doi: 10.1007/s11738-0131304-Z

12. Giliberto L, Perrotta G, Pallara P, et al (2005) Manipulation of the blue light photoreceptor cryptochrome 2 in tomato affects vegetative development, flowering time, and fruit antioxidant content. Plant Physiology 137:199-208. doi: 10.1104/pp.104.051987

13. Hoenecke ME, Bula RJ, Tibbitts TW (1992) Importance of "blue" photon levels for lettuce seedlings grown under red-lightemitting diodes. HortScience 27:427-430. doi: 10.21273/hortsci.27.5.427

14. Hogewoning SW, Trouwborst G, Maljaars $\mathrm{H}$, et al (2010) Blue light dose-responses of leaf photosynthesis, morphology, and chemical composition of Cucumis sativus grown under different combinations of red 
and blue light. Journal of experimental botany 61:3107-3117.

doi: $10.1093 /$ jxb/erq132

15. Kamiya A, Ikegami I, Hase E (1981) Effects of Light on Chlorophyll Formation in Cultured Tobacco Cells I . Chlorophyll Accumulation and Phototransformation of Protochlorophyll ( ide ) in Callus Cells under Blue and Red light. Plant and cell physiology 22:1385-1396.

16. Kim HH, Goins GD, Wheeler RM, Sager JC (2004) Green-light supplementation for enhanced lettuce growth under red-and blue-light-emitting diodes. HortScience 39:1617-1622. doi: 10.21273/hortsci.39.7.1617

17. Klemo M, Biti B (2018) Nitrate Concentration in Plant Products of Albanian Market. Knowledge International Journal 28:1289-1294. doi: 10.35120/kij28041289m

18. Kurilčik A, Miklušytè-čanova R, Dapkūnienè $S$, et al (2008) In vitro culture of Chrysanthemum plantlets using lightemitting diodes. Central European Journal of Biology 3:161-167. doi: 10.2478/s11535-008-0006-9

19. Lee SH, Tewari RK, Hahn EJ, Paek KY (2007) Photon flux density and light quality induce changes in growth, stomatal development, photosynthesis and transpiration of Withania Somnifera (L.) Dunal. plantlets. Plant Cell, Tissue and Organ Culture 90:141-151.

doi: 10.1007/s11240-006-9191-2

20. Leong TY, Anderson JM (1984) Adaptation of the thylakoid membranes of pea chloroplasts to light intensities. I. Study on the distribution of chlorophyll-protein complexes. Photosynthesis research 5:105115.

21. Lillo C (1994) Light regulation of nitrate reductase in green leaves of higher plants.
Physiologia Plantarum 90:616-620. doi: 10.1111/j.1399-3054.1994.tb08822.x

22. Lillo C, Appenroth KJ (2001) Light regulation of nitrate reductase in higher plants: Which photoreceptors are involved? Plant Biology 3:455-465. doi: 10.1055/s2001-17732

23. Lin KH, Huang MY, Huang WD, et al (2013) The effects of red, blue, and white light-emitting diodes on the growth, development, and edible quality of hydroponically grown lettuce (Lactuca sativa L. var. capitata). Scientia Horticulturae 150:86-91.

doi:https://doi.org/10.1016/j.scienta.2012.1 0.002

24. Lopez-Juez E, Hughes MJ (1995) Effect of blue light and red light on the control of chloroplast acclimation of lightgrown pea leaves to increased fluence rates. Photochemistry and photobiology. 61:106111.

25. Massa GD, Kim HH, Wheeler RM, Mitchell CA (2008) Plant productivity in response to LED lighting. HortScience 43:1951-1956. doi: 10.21273/hortsci.43.7.1951

26. Matsuda R, Ohashi-Kaneko K, Fujiwara K, Kurata K (2007) Analysis of the relationship between blue-light photon flux density and the photosynthetic properties of spinach (Spinacia oleracea L.) leaves with regard to the acclimation of photosynthesis to growth irradiance. Soil Science and Plant Nutrition 53:459-465. doi: 10.1111/j.17470765.2007.00150.x

27. McAllister F and (1937) Wavelengths of radiation in the visible spectrum promoting the germination of lightsensitive lettuce seed. Smithsonian Inst. Publs., Misc. Collections 96:1-8.

28. Morgan DC, Smith H (1979) A systematic relationship between phytochromecontrolled development and species habitat, 
for plants grown in simulated natural radiation. Planta 145:253-258.

29. Naznin MT, Lefsrud M, Gravel V, Azad MOK (2019) Blue light added with red LEDs enhance growth characteristics, pigments content, and antioxidant capacity in lettuce, Spinach, Kale, Basil, and sweet pepper in a controlled environment. Plants. doi: 10.3390/plants8040093

30. Pandey SK, Singh H (2011) A Simple, Cost-Effective Method for Leaf Area Estimation. Journal of Botany 2011:1-6. doi: $10.1155 / 2011 / 658240$

31. Pinho P, Jokinen K, Halonen L (2012) Horticultural lighting - Present and future challenges. Lighting Research and Technology 44:427-437. doi: $10.1177 / 1477153511424986$

32. Poudel PR, Kataoka I, Ryosuke M (2008) Effect of red- and blue-light-emitting diodes on growth and morphogenesis of grapes. Plant cell, tissue and organ culture 92:147-153. doi: 10.1007/s11240-0079317-1

33. Sæbø A, Krekling T, Appelgren M (1995) Light quality affects photosynthesis and leaf anatomy of birch plantlets in vitro. Plant Cell, Tissue and Organ Culture 41:177-185.

34. Santamaria P (2006) Nitrate in vegetables: Toxicity, content, intake and EC regulation. Journal of the Science of Food and Agriculture 86:10-17. doi: 10.1002/jsfa.2351

35. Schwartz A, Zeiger E (1984) Metabolic energy for stomatal opening: Roles of photophosphorylation and oxidative phosphorylation. Planta 161:129-136. doi: https://doi.org/10.1007/BF00395472

36. Senger H (1984) Blue light effects in biological systems. Springer-Verlag, Berlin

37. Sharkey TD, Raschke K (1981) Effect of Light Quality on Stomatal Opening in
Leaves of Xanthium strumarium L. . Plant Physiology 68:1170-1174.

doi: $10.1104 / p p .68 .5 .1170$

38. Sumanta N, Haque CI, Nishika J, Suprakash R (2014) Spectrophotometric Analysis of Chlorophylls and Carotenoids from Commonly Grown Fern Species by Using Various Extracting Solvents. Research Journal of Chemical Sciences Res. J. Chem. Sci 4:63-69.

39. Takemiya A, Takahashi Y, Shimazaki K (2007) Leaf temperature reduction by blue light-dependent stomatal opening. Cryobiology and Cryotechnology 53:1-5.

40. Walters RG (2005) Towards an understanding of photosynthetic acclimation. Journal of Experimental Botany 56:435-447. doi: 10.1093/jxb/eri060

41. Yanagi T, Okamoto K, Takita S (1996) Effects of blue, red, and blue/red lights of two different PPF levels on growth and morphogenesis of lettuce plants. Acta Horticulturae 440:117-122. doi: 10.17660/ActaHortic.1996.440.21

42. Yorio NC, Goins GD, Kagie HR, et al (2001) Improving Spinach, Radish, and peak height), which closely matches a peak absorbance of chlorophyll (McCree, 1972). Lettuce Growth under Red Light- Although red LEDs have great potential for use as a light source to drive photosynthe- emitting Diodes (LED. HortScience 36:380-383.

43. Zeiger E (1984) Blue light and stomatal function. In Blue light effects in biological systems. Springer, Berlin, Heidelberg. 